contained a number of disincentives outlined by the authors. The reported result was a stifling of productivity. As reforms began to be implemented, the collective turned ownership of animals over to nomads who had previously herded them as a delegated task. Many herders were reluctant to give up the advantage of the marketing and other services provided by the collective. Soon they turned the collective into a shareholding company, thus maintaining some advantages of large-scale organization. In general, the translation to a market system meant hardships. Trade goods from abroad disappeared and disposable income declined, trends that evoked a return to traditional crafts, such as felt making, and traditional agricultural supplements, such as growing barley. The more difficult times that came with the termination of state subsidies, however, did not lead to discouragement.

The authors found that people felt empowered by the absence of disincentives, as they were able to benefit from working harder. They were optimistic about successfully providing for their needs themselves. Goldstein and Beall researched only the first year of decollectivization, still too early to provide definite answers to several critical questions. Will extreme economic and social inequities of the past reemerge? Will trade with Xinjiang and other parts of Western China replace the missing trade with East European socialist countries? Will there be destabilizing pressure placed on the environment due to a high birth rate and the expansion of herds still viewed as a traditional form of wealth? If these issues are to be assessed in subsequent phases of the nomads capitalist transition, the authors here provide a solid foundation and exemplary model for other researchers to follow. The essential contribution of this book is its insight into how national policy changes play out in the lives and livelihood of a little-known people who were remote and inaccessible to observers from Western countries.

\title{
Native Canadian Anthropology and History: A Selected Bibliography (revised edition) by Shepard Krech III, University of Oklahoma Press, 1994. 212 pp.
}

\section{Reviewed by Bruce G. Miller, University of British Columbia Department of Anthropology and Sociology.}

There can be only sympathy for someone attempting to select three thousand citations out of all of the publications on the anthropology and history of Canadian First Nations. Shepard Krech III's aim in attempting this is to prepare a bibliography for undergraduates to use to in creating well-researched projects in the fields of Native studies, anthropology, and history, and also to direct specialists to useful but obscure sources. The volume is intended to be used together with comprehensive bibliographies, a number of which are listed in these pages. Krech did not omit material which has been poorly reviewed, preferring to allow readers to make up their own minds about quality--surely a good thing given the rapidity with which evaluations change. Krech did omit dissertations, theses and "gray matter," arguing that these are hard to get hold of. The volume focuses on the 
literature produced between 1980 and 1990, but there are many earlier citations, and some from as recently as 1993. The citations are organized into 19 sections. The first three chapters concern bibliographic sources; the following eight are entitled "regional and ethnic sources;" and are organized by culture area; and the last eight are "special topics." These topics are historiography, the fur trade, missionaries, education, health and disease, art and material culture, gender, and political, legal, and constitutional issues. There is an index of authors, which is valuable because in many cases the citations for any single scholar are divided among several chapters. Finally, there is a 26 page introduction to the volume.

Krech has achieved what he hoped; this volume is useful for undergraduate students who are struggling to find their way into the academic literature. The book does, as promised, provide interesting, overlooked citations for professionals. It is helpful for both students and professionals to have in one place in-depth, (although incomplete) bibliographies of such noted scholars as Sally Weaver, Michael Asch, Noel Dyck, Robin Ridington, Catherine McClellan, and many others. These personal bibliographies provide a sense of what Canadian historians and anthropologists have been concerned with, and how interests have shifted over the years.

I wonder, however, what the future will be for volumes of this sort in an age of powerful, new computer-based bibliographies. Many of my own students, for instance, are now quickly able to produce more focused and complete bibliographies than the one on gender in this volume. Furthermore, because of the rapidity of change for First Nations in Canada (perhaps especially British Columbia, where treaties are being negotiated and land claims are currently being contested in court and in negotiation) the section on political, legal, and constitutional issues is already badly out of date. There will without question, be a continuing need for annotated bibliographies that lead readers into the significant debates, but this volume is not intended to do such a task.

Krech's text introduces his book, not the literature, with some exceptions. Krech reveals his viewpoint explicitly on which he thinks are the best sources covering a given topic, and such passages are the most helpful in the book. There is some discussion of approaches to ethnohistory and of the fur trade literature, both topics appropriately reflecting the author's personal interests.

There are several relatively minor points that I cannot let pass. First, given the great difficulty in selecting entries, it is unclear to me why citations that do not directly consider Canadian topics are included. Such entries (all very good ones in their own right) concern Iroquoian contributions to the US constitution, treaty issues and ecological histories in Washington state, and so on. Second, it is also unclear why so many obsolete pieces treating alcohol abuse (some written decades earlier than the volume's targeted period) need be included within the otherwise good section on health and disease. Finally, the editorial decision to use outdated terminology for First Nations seems indefensible. Because such names are no longer accepted by the First Nations themselves, and generally are no longer used by academics working with and situated near these First Nations, it is time to stop justifying these outmoded designations and adopt newer terminology. There is no convincing reason to use the terms Bella Coola or Nootka, for example, and people ought to get used to this, or at least address the issues that connect the name changing by aboriginal groups and the politics of decolonization. 